MACIEJ D. KRYSZCZUK*

Independent Scholar

MICHAŁ WENZEL**

SWPS University of Social Sciences and Humanities

DOI: $10.26485 / \mathrm{PS} / 2017 / 66.4 / 3$

\title{
NEO-LUDDISM: CONTEMPORARY WORK AND BEYOND
}

\begin{abstract}
Neo-Luddism is based on the belief that modern societies cannot transcend the (capitalist) division of labour and official labour institutions. This paper traces the intellectual sources of Neo-Luddism, proposes a typology, and examines its relevance for studying contemporary work. We differentiate four types of Neo-Luddism. Economic Neo-Luddites (1) act on anti-libertarian instincts and advocate re-agrarisation or reindustrialisation to prevent unemployment and degradation of the community. They are apologists of primeval groups such as the family, nation or religious community, and they postulate reconciling work efficiency with non-economic values and collective life. This attitude is linked in the economic sphere to romantic-pastoral Neo-Luddism (2), associated with environmental movements questioning modern mass production, manifested in fashion for ecology, vegetarianism, and naturalist escapism. The romantic variety may or may not have religious connotations. Furthermore, we distinguish (3) spiritual-ideological Neo-Luddism. This trend is characterized by scepticism toward mainstream science and technology and, broadly, to materialist epistemology. A separate strand is the so-called anarchic Neo-Luddism (4), which directly draws inspiration from the sabotage tactics used by original Luddites. It attacks the state, technology

* Dr; e-mail: maciej.kryszczuk@gmail.com

** Dr, Institute of Social Sciences, Faculty of Humanities and Social Sciences; e-mail: mwenzel @ swps.edu.pl
\end{abstract}


and science (the technosphere) with methods borrowed from the 'enemy'. Its representatives are anarchoprimitivists, cultural saboteurs, cyberpunk culture, hackers, etc.

Keywords: Neo-Luddism, capitalism, division of labour

Scholars of different traditions agree that Luddism, as a social movement and a set of specific anti-modernization attitudes, was born at the turn of the $18^{\text {th }}$ and $19^{\text {th }}$ centuries. At that time, and for the first time on such a broad scale, English craftsmen massively lost their jobs in connection with the industrial revolution and the introduction of machinery into factories. As a result, in place of skilled craftsmen poorly trained workers were employed, who after a short training were able to handle weaving and knitting machines. The economic cause of the subsequent reactionary riots was the fear that introducing machinery into factories would contribute to poverty and unemployment among workers and would lead to the collapse of craftsmen's workshops. According to legend, the name of the movement comes from the worker Ned Ludd, who in 1779 furiously shattered two knitting frames. ${ }^{1}$ This act of destruction has become a symbol of resistance to the all-encompassing mechanization of industry and the replacement of workers with modern technical devices. Over time, Luddites became so troublesome for the rest of the population that the British army was used to quell them. ${ }^{2}$ The high point of Luddite riots occurred in 1811-1813 (Nottingham, Yorkshire, Lancashire, Derbyshire, Leicestershire), when the movement was already organized and capable of exercising pre-democratic pressure (collective bargaining by riot). It was met with waves of acute government repression, including punishment by exile and death. Further waves of riots in the years 1816-20 were caused by the recession in the British economy after the Napoleonic Wars, and the last spectacular acts of the Luddites took place in the 1830s. Afterwards, the movement died out.

1 "At least since the followers of Ned Ludd smashed mechanized looms in 1811, workers have worried about automation destroying jobs. Economists have reassured them that new jobs would be created even as old ones were eliminated. For over 200 years, the economists were right. Despite the massive automation of millions of jobs, more Americans had jobs at the end of each decade up through the end of the $20^{\text {th }}$ century. However, this empirical fact conceals a dirty secret. There is no economic law that says that everyone, or even most people, automatically benefit from technological progress.” [Brynjolfsson, McAfee 2011: 36]

2 "The army sent by British parliament to put down Luddites in the peak period exceeded numerically the forces assigned to Wellington to fight Napoleon on the Iberian peninsula" [Muszyński 2016: 2]. This apparently indicates the military superiority of British workers over French soldiers. 
However, as we will see, it later came back to life, facilitated by the internet, which has become a platform for new Luddite movements. ${ }^{3}$ The goal of this paper is to propose a typology of contemporary strands of Neo-Luddism, taking into account their relation to the state, ideological orientation, and methods of action.

\section{INTELLECTUAL TRADITION OF LUDDISM}

Luddism is not an intellectual tradition per se. Its ideological foundations are latent and varied. In this paper we approach it from a sociological perspective, fully acknowledging that this is just one of many possible approaches. In this view, Neo-Luddism is a result of the normative affirmation of the Gemeinschaft as understood by Ferdinand Tönnies [1971], or the return to mechanical solidarity [Durkheim 1999]. Both the "natural will" (juxtaposed to the rational will by the former) and the penal law (as opposed to the restitutive law by the latter) correspond to the pre-modern human condition, which (not necessarily in the interpretation of these authors) is more human or primeval. In his classic work on division of labour, Emile Durkheim created a theory of social ties that sheds light on some aspects of Neo-Luddism. Inasmuch as this topic is well known, let us use a schematic shortcut: the notions of mechanical and organic solidarity correspond to two types of law: repressive (punishing for sins) and restitutive (recreating the status quo), linked to different types of organization of social life. The modern division of labour, with its individualistic approach to the human being, is based on organic solidarity. Social relations usually take the form of a contract (e.g. an employment contract), whereas under mechanical solidarity, which prevailed in pre-modern societies with a low degree of professional differentiation, social relations consisted in the convergence of individual and collective identity, i.e. an individual was shaped to reflect and resemble the community. The emergence of personality as a bundle of identities has complicated the processes of supervision and organization: control of individuals by the system (government, media, corporations), and control of the individual over the uncertainty posed by the environment. In other words, organic solidarity, unlike mechanical solidarity, emerges due to the existence of natural disparities between people derived from culturally coordinated social roles that allow individuals to complement themselves in order to better achieve their own goals [see Durkheim 1999].

3 An internet search engine returns 98,900 hits for the term "Neo-Luddism" (data as of 27.07.2017). 
There is another aspect of the labour market that, for our purposes, can be deduced from Durkheim's theory of social ties. The growing complexity of socioeconomic life is accompanied by the expansion of institutional forms of organization and legal control (civil law, including labour codes), which require the employment and maintenance of appropriate personnel. It is true that different societies transit from mechanical solidarity to organic to a different degree and at a different pace, but the tendency to establish formalized, codified regulation is universal and results in widespread bureaucracy (not only in the public sector). Existing differences in civilizational standards, resulting from both cultural and political differences, as well as the material situation of a given society, are gradually becoming blurred as a result of globalization processes. For example, the establishment of a ministry for the protection of tropical forests may be locally specific, but any modern state must have the equivalent of a ministry of finance or justice.

Unification of civilization standards (as a certain variant of convergence) leads to the structure of the labour market in which there is a constant increase in the number of jobs and professions directly or indirectly related to: a) the functioning of the modern state (whether it be a democratic state or an authoritarian regime); b) the process of informationisation of the economy. In developed socio-political organisms, large structures cannot be effectively managed without the appropriate administrative personnel, databases etc., some of which can be successfully commercialized. The Neo-Luddist political-economic program in the liberal version, entails abandoning certain forms of contract (e.g. employment contracts), and giving up technological facilities (e.g. the media) and services guaranteed by the state (e.g. universal mandatory vaccination). It also involves some form of escapism from the media-information regime, which has become a source of attitudes and values. It seems that this is the (latent) platform of opponents of interventionism, who, in the name of individual freedom, demand lower taxes, reduced bureaucracy, and liberalization of restitutive law. In short, such a program postulates reducing the welfare state and returning to primitive communities and mechanical solidarity, with its repressive criminal law, operating on principles of sin and penance.

This interpretation of Tönnies or Durkheim provides a background for interpreting the evolution of societies, as well as explaining the utopian contemporary visions of the conservative-modernist community (modern nationalism). The Western model of modernization, which produced the global internet technology, has since its inception contained both the potential for positive self-reflection (a critical approach to the idea of progress) and negative self-destruction (the tech- 
nological effectiveness of the Holocaust). In its optimistic version modernization, as the driving force for all humanity, also encompassed the inclusion of different cultural patterns (such as Confucianism, Hinduism, Christianity, etc.), incorporating attributes that serve adaptation to change (see Pobłocki 2017). At present, the semantics of modernization is broad and heterogeneous. It includes tradition and continuity, progress and regression, reason and emotion, myths and facts; and it contains an unorthodox reconciliation of the individual and the collective. This conflicting coexistence, on equal rights, of scientific truth, cosmology, political ideology, cultural patterns, and morality serves "subjectivity in difference."

As we know, in the first phase of industrialization, professionalization allowed for separation of the sphere of work from the private, thereby contributing to the process of empowerment of the masses (the working class). The system worked well when it was based on widespread employment, and the redistributive institutions levelled out drastic socio-economic differences and ensured an increase in civilization standards (in education, health care, pensions, etc.). The subsequent evolution of capitalism, in which smart robots enter the stage, will probably require a change of approach to the idea of progress. Permanent modernization, without a moment of rest, contradicts the cultural duality: the need for rest and work, stability and movement, continuity and rupture, etc. A large number of critical works have been written about the destructive effects of technological progress, and more broadly on the rationalistic heritage of the Enlightenment [Bauman 1989; Horkheimer, Adorno 2002; Zybertowicz et al., 2015]. Cataluccio [2006: 117] called it the golem that has escaped us, the power that brutally crushed us, one which we unleashed ourselves driven by the illusion that we are masters of the world.

The (latent) ideological interpretation of Luddism is presented in the works of sociologists, historians, philosophers and politicians [see Hobsbawm 2013; Nowak 2013]. In the 1990s, Keith Grint and Steve Woolgar [1997: 39-63] distinguished several perspectives within the interpretive tradition of Luddism. The first emphasizes the rationality of technology and the irrationality of the Luddites, and is part of the mainstream (liberal, western) understanding of civilizational progress, which is ideologically linked to the theory of universal modernization. Technology is presented here as an external and autonomous factor of development that determines the socio-economic organization and production relationships. Such a view can be characterized as technological determinism, which does not analyse the origins and effects of technological inventions.

In the interpretation close to Marxism, technology itself is economically and socially rational, and the realm of economic exploitation is capitalism. As Marx 
[1887: 287] noted, "the contest between the capitalist and the wage-labourer dates back to the very origin of capital. It raged on throughout the whole manufacturing period. But only since the introduction of machinery has the workman fought against the instrument of labour itself, the material embodiment of capital. He revolts against this particular form of the means of production, as being the material basis of the capitalist mode of production."

In a narrower sense, new information technologies are sometimes considered as an effective means of articulating group interests (e.g. rights of internet users versus intellectual property rights). Depending on the interests involved, the enemy of the Neo-Luddites is either the system as a whole or individual elements, including the technosphere, the "free market", or "traditional" popular culture offered by the mainstream. For Marxists, technology is only negative when combined with a capitalist mode of production that use machines commercially to exploit people. Since capitalism is one of the factors of modernization, its rejection requires either a redefinition of modernity, or its negation (in anticipation of the revolution). The system can therefore be countered using its own tools, but economic rationality escapes civic control.

Luddism (and Neo-Luddism) is rejected by economic (neo-)liberals. In contrast to Marxists, economic liberals have warned against the nostalgic pessimism about industrial civilization, on the ruins of which a socialist utopia was to be born: "Those who want to set the clock of history back ought to tell people what their policy would cost. ... It is certainly possible to stop the further progress of capitalism or even to return to conditions in which small business and more primitive methods of production prevail. A police apparatus organized after the pattern of the Soviet constabulary can achieve many things. The question is only whether the nations that have built modern civilization will be ready to pay the price." [Mises 1957: 237-238].

The emergence of a modern, anti-capitalist counter-culture rejecting technological progress can be traced back to the first half of the twentieth century, when the process of industrialization entered its next phase, the culmination of which was in the culture of modernism, and in both the economy and technology many revolutionary innovations emerged, for example, automated (Fordist) production and mass media development. Among the visionaries and critics of scientific, technical and economic progress are: Jacques Ellul [1964], Theodore Roszak [1986] and Ernst Schumacher [1973]. As Łukasiewicz [2000: 43] observes, "Contemporary opponents of technology condemned not only, as Marx did, the socio-economic system in which it was developed and implemented, but also the very notion of technology. They recognized science and technology as 
autonomous and deterministic forces of their own, beyond the control of society. They believed that technology that requires prudent and rational behaviour, developed skills and a high degree of organization, acts in dehumanizing way, destroying quality of life, dominating people, cutting them off the natural world, and inhibiting them and their emotional development."

Automation is increasingly endangering human work. Consequently, there has been a sharp rise in interest in Luddism in humanistic critiques of Western industrial culture, and clear signals of civilizational escapism from the so-called mainstream modernization. This is reflected in such phenomena as: criticism of mass production and corporate organization; the affirmation of renewable energies; natural foods or traditional (rural) lifestyles; as well as projects introducing pre-modern modes of economic organizations. We analyse them as a package, ignoring for now the risk of antinomies. In the hypothetical conditions of abundance came the concept of the so-called circular economy [Pearce, Turner 1989], which proposes business models based on the conservation of raw materials (recycling), environmental protection, and durability of goods. The idea of a "zero marginal cost society" based on collaborative communities from imaginary history, is also described by Rifkin [2016]. Anthropologists of everyday life write about the processes of traditionalization, retraditionalization, relocation, indigenization, customization, and transculturalization, parallel to the modernization of the western world, pointing to the complexity of globalizing modernity [see Kuligowski 2012: 105-135]. These are not new dilemmas (compare John Hobbes's dispute with Jean Jacques Rousseau). However, the current context (the IT revolution, economic globalization, mediatization, disenchantment with science, automation of work, etc.) has greatly expanded the scope and impact of such attitudes and ideologies on the mainstream public opinion.

The emerging form of critique of global mass culture targets consumerist propaganda used by marketing, advertising and political actors, and the primacy of (excessive) economic growth, which is contrasted with an idealized past of stability, social security, and full employment (the myth of a golden age). While "old" Luddism was purely economic (utilitarian), and its main postulate was the protection and preservation of workplaces, the aesthetic-intellectual NeoLuddism rejects the mainstream value system of Western civilization, linked to the rationalist tradition of Enlightenment, mass culture, commercialization, individualization, etc. In addition to critique of capitalism, Neo-Luddites blame economic liberalism for bringing about the so-called "crisis of values", equating liberalism with laissez-faire, unbounded freedom. They should be differentiated from conservative defenders of the idea of the immanent dignity of human work, 
who combine their critique of capitalism with egalitarianism and a belief in social justice within a chosen locale or religious community.

Neo-Luddites have their congresses, where they prepare action plans. They see themselves as having an historical role in the struggle against the capitalist (post) industrialization and propose the following: "1) grounding their movement in philosophical reasoning, in certain established intuitions and theories, outlined by the well-known anti-technological movement, represented by such thinkers as Aldo Leopold and Lewis Mumford, Jacques Ellul, Paul Goodman, Rachel Carson and Wendell Berry, as well as contemporary Neo-Luddites; 2) disseminating a broadly understood Luddite philosophy, attempting to change the basic worldview of our technical society, to break away from the false deities which it venerates, such as materialism, rationalism, and humanism, which claim that the ultimate goal in life is to accumulate personal wealth, and their idols of exploitation, domination, profit, progress and growth; 3 ) replacing the dangerous false gods with guides who have proven themselves to be trustworthy, solid, and a source of inspiration for human society since the earliest times; who create forces, paradigms, systems and organisms of the natural world, a wonderful, sacred, invaluable and overwhelming divine biosphere on which every life depends - because then we will learn to choose and evaluate, create and build a technique of life, in all its harmony, variety and beauty." 4 There is a remarkable compatibility with the postulate of degrowth, found even in the publications of the Club of Rome and the European Parliament. Here is what the official Neo-Luddites specifically decided at their Congress: "1) everyone can take care of some piece of land, even a flower bed; 2) we can give up watching television; 3) we can limit or even give up driving; 4) we can eat the food produced in the area, cook our own meals, and invite our neighbours to dinner; 5) we can reduce the traffic of vehicles in the immediate neighbourhood." In addition, Neo-Luddites encourage support for local libraries and admonish that destroying someone's property is not the most effective way to make changes. It is difficult to disagree with such a claim.

The warnings issued by Neo-Luddites of different ideological orientations have in common the perception of a link between digital technology and the infantilization of culture: "Consumerism urges us to reach back to what we used as children and what the Bible told us to renounce, and to step into the new world of electronic toys, games and gadgets that make up the modern digital adult playground; the market apparently recognized that people do not have to grow up anymore. Instead of getting schools to help children grow out of toys,

4 Source [access 24.08.2017]: http://www.zb.eco.pl/zb/150/luddyzm.htm 
we bring toys to schools - video games and computers as learning aids, as well as commercially sponsored television in classrooms. ... Traditional teaching methods cannot compete with the charm of the world of commercial games in which children become heroes or themselves determine the fate of Harry Potter." [Barber 2008: 25].

\section{IDEOLOGICAL PERSPECTIVES OF NEO-LUDDISM IN $21^{\text {ST }}$ CENTURY}

It would take a separate monograph to give a full methodological justification for the use of the term Neo-Luddism, the clarification of its meanings and connotations, as well as the construction of a typology of Neo-Luddism. The related concept of "retrotopia" has become popularized in a book by Zygmunt Bauman [2017]. In some respects, our own interpretation of Neo-Luddism links to the philosophy of Daniel Dennett's recently published book [2017] "From Bacteria to Bach and Back: the Evolution of Minds." Although we take a different (economic, sociological and anthropological) perspective and try to remain intellectually and emotionally detached from the subject matter, some similarities exist. They consist in the synthesis of the hypothesis of the "explosion of ignorance" with the observation of restricted rationality of industrial civilization and a set of more or less conscious reactions to technological progress mediating the lives of modern humans. These cultural phenomena are related to the slow but inevitably increasing displacement of people from production processes.

Practical visions of the future of human work must include, in addition to technological progress, the development of commodity markets and the objectives of the state economic policy, including changes in the broadly understood sphere of culture. We have already mentioned the shortcomings of Enlightenment techno-utopia, with its excessive optimism about the future created by unlimited market exchange. On the opposite pole are ideological currents sceptical or negative with respect to progress, imagined along the lines of a stereotypical narrative of a rationalistic Enlightenment that does not take into account the apocalypse. ${ }^{6}$

5 Both Bauman and an occultist named John Michael Greer [2016] use the term "retrotopia" and voice a critique of economic liberalism (capitalism), while stressing the futility of conservatism. The term "Neo-Luddism" covers a broader range of attitudes to the mainstream civilization; not all of them are utopian or irrational.

6 For instance, Kirkpatrick Sale [1995; an American environmentalist] and Kalle Lasn [2000; a Canadian writer and filmmaker] identify as Neo-Luddists. Their texts contain some further explications of the movement's goals and tactics. 
The dispute between progressives and reactionaries has a long history, but never before has the scale and pace of scientific and technological interventions into social life been so great. We can see this in the pace of automation of work, first with mechanization of manual labour, and then with displacement by artificial intelligence of tasks requiring human intelligence (whatever it is). We use the term Neo-Luddism to describe, in different ideologies, a negative attitude towards scientific and technological human achievements (including achievements in the rationalization of production processes and allocation of capital), to specialized division of labour based on expert knowledge, and to automation, robotics and artificial intelligence. ${ }^{7}$ We posit that this is not a homogeneous attitude. There are different varieties of opposition to "forces of progress" and different ways of understanding progress, and rejection can have varying degrees of intensification and rationalization: from total negation and cultural alienation (eremitism) to constructive criticism, reflected in a targeted rejection of only some manifestations of progress. The common denominator of Neo-Luddist attitudes is an affirmative attitude toward work, but understood differently from the Enlightenment tradition of professional division of labour, which is also seen as a source of danger by Neo-Luddites.

Our understanding of Neo-Luddism is based on the belief that a citizen of a highly developed country is not able to go beyond the (capitalist) professional division of labour and official labour institutions, as both markets and nation states have dominated the sphere of production and consumption. Neo-Luddist attitudes take on a variety of forms that cannot be attributed to conventional political, economic, or religious doctrines. ${ }^{8}$ The notion of Neo-Luddism should include a description of distinctive elements in various attitudes in new global, institutional and cultural contexts. Unlike their predecessors, Neo-Luddites do not destroy machines (software programs, computers, smartphones, etc.) today, because modern tools (especially information technology) are not used for work only and are not consciously perceived and blamed for unemployment. There are other, less obvious syndromes of "opposition to technology," such as rejection of mass media coverage. The illusory belief in the possibility of creating an information agenda, based on independent sources, is shared not only by the young, educated active Internet users, but also by adherents of "alternative explanations" and followers of various conspiracy theories.

7 We do not use the term alter/anti-globalism, as it usually carries a negative attitude to cultural and economic globalization, but does not question technological development.

8 Neo-Luddism contains elements of Occidentalism, understood as criticism of western civilization, often encompassing hostility to modernization. 


\section{Economic Neo-Luddism}

Economic Neo-Luddism highlights the necessity of democratic governance of capitalism, which is to blame, among other things, for technological unemployment, social inequality, and poverty. A modification of current forms of liberal social democracy leads to a vision of social order in which the general principles of free-market exchange (competition, private ownership) are preserved, but in a reduced version subordinated to public management. Sustainable development depends partly on the return to traditional or disappearing economic models, e.g. lengthening the production chain, creating parallel labour markets, promoting cooperatives or neighbourhood barter services, etc. The underlying idea is not rationalistic specialization or the professional division of labour, i.e. introduction of processes to improve efficiency, but the exact opposite, i.e. abandoning all technologies or processes that eliminate the worker from the production cycle, even when it is justified by utility maximization considerations [see Rifkin 2016].

The potential for system errors in such a design is enormous, because the ultimate responsibility rests with a human, not a machine. "Correct" narratives rather than rationalistic calculations oriented on long term-effects acquire political meaning. Neo-Luddist "social calculations" include not only unemployment costs and other economic outcomes, but also political and cultural externalities. Economic Neo-Luddites with anti-liberal attitudes tend to postulate either reagrarization or reindustrialisation to prevent unemployment and the degradation of (closed) communities. This trend sometimes idealizes the primitive group (family), nation, or religious community, based on the principle of reconciling work efficiency with non-economic values and collective life. ${ }^{9}$

In the economic dimension, Neo-Luddism is opposed to the humanistic principle, which claims: the more jobs are automated, the more the labour market shifts towards occupations requiring specific human competence. However, there appears to be no convincing definition of what these supposed irreplaceable skills are. While earlier stages of civilizational development replaced menial occupations, sophisticated automation and artificial intelligence are now capable of replacing highly skilled jobs. An optimistic view holds that people have been and will be able to make a living providing useful work as technology progresses, because the society is able to generate more and more different kinds of needs and

9 Ha-Joon Chang draws our attention to an interesting parallel: "The official economic ideology of Taiwan is comprised of three principles of Sun Yat-Sen, the founder of Kuomintang: minzu (nationalism), minquan (people's power) and minsheng (people's prosperity). These principles entail state ownership of key economic sectors.” [Chang 2016: 189]. Many contemporary national-populist parties would agree with Sun-Yat Sen's principles. 
thereby provide real opportunities to satisfy them, giving people a meaningful and socially useful work. Neo-Luddites, sceptical about progress, ask however: what will happen when machines overtake humans in every way or in almost all respects, leaving only a narrow group of engineers, programmers and individuals with the highest level of creativity not replicable by machines? It appears that IT specialists, paradoxically, are among the most endangered professions. "The IT revolution, which is the result of the invention of the computer first and later of the Internet, is replacing human beings by computers in the sector of broadly understood information services on a global, cross-border scale." [Celary 2013: 7]

As a result, Neo-Luddites naturally fall into an unintended alliance with technocratic etatists: for the former there is a case for limiting technological development, while the latter advocate social engineering under the compulsory welfare state or state administration of social needs, satisfied with services provided by professional officials (technocrats). ${ }^{10}$ [Wiśniewski 2017].

\section{Romantic-pastoral Neo-Luddism}

Romantic-pastoral Neo-Luddism is linked to pro-environmental movements challenging modern mass production, such as the fashion for ecology, municipalism, vegetarianism, and local naturalism. The attitude of modern Neo-Luddites is often characterized by some form of "return to nature" and affirmation of a world that is homey, familiar, closed, traditional, stable, safe etc. Renouncement of material goods and folk escapism (more or less consciously performed) are recognized as a means of recovering spontaneous and direct human relationships that improve the mental and physical condition of people. "Great ideologies have their own simplified versions and popular variants deprived of intellectual depths. Naturism is environmentalism reduced to the terms of 'nature conservation' and 'return to nature'. These seemingly simple and attractive catchwords are not new and are not too rational. Resistance to technology assumed the form of a 'machine destroyers' movement as early as in the nineteenth century. At the dawn of industrial civilization, the romantic-conservative ideas of 'rejection of the artificial world' and 'return to nature' were born. These ideas were voiced in France by Francois R. de Chateaubriand or in England by the irrationalist John

10 "Before, in social sciences the notion of technocracy was used to emphasize the imperative of professionalism in controlling public affairs, including macroeconomic ones. However, under the pressure of representative democracy (or rather its illusion, because someone ignorant cannot well represent the authentic interests of their electorate), technocracy is pushed aside, replaced by amateurship, political show business, populism, or simple stupidity [Kołodko 2013: 324]." 
Ruskin. Naturism, which rejects human interference in nature, is today a deviation of environmentalism, but it is appealing to simple and conservative minds. What is naturism today? Proponents of this naive variety of environmentalism are inclined to accept at least three false principles: 1 . Nature is the basic human environment; 2. Distance away from nature harms us, so we should - wherever possible - 'return to nature'; 3. By interfering with nature and manipulating it, people spoil and destroy it, and therefore nature must be protected from human activities. The acceptance of these three principles of naturism leads to behaviour that is indifferent to morality, customs and the economy and causes many irrational demands and activities." [Opara 2009: 196-197, 198]

The romantic-pastoral trend may or may not have religious connotations, which in turn have a heterogeneous relationship to the humane treatment of animals (hunting) and plants (forest cutting). The ethical disputes around hunting concern both the act of killing and in general eating of animals. Although domestic animals differ (also in terms of death) from wild animals, it does not follow that the act of killing is immunized [see Kruczyński 2008]. The allegedly romantic characteristics of the culture of hunting clash with the rationalism of industrial slaughter, while the awareness of these differences is also a rationalizing element of choosing sides of the ideological dispute.

A relatively new aspect is the intensive moral controversy over the so-called "animal rights". Equal treatment of different beings, regardless of species, and the imperative of avoiding suffering are postulates that derive from the humanistic principle of equality between people. The arguments of advocates of "species equality" refer to the holistic vision of the Earth as a community of all living entities (including plants), living in empathy and symbiosis. On the other hand, arguments of a religious nature are raised (the significant qualitative distinction of homo sapiens among species), as well as examples of distinctions in human rights and obligations (e.g. age criterion for electoral laws). Fukuyama [2008] puts it succinctly: the nature of laws depends on the nature of the species. Let us add that the relation of humans to other species affects the labour markets, as it includes the social production of goods for animals (fodder, veterinary products, services for pets, etc.) and plants (e.g. non-productive garden cultivation).

\section{Spiritual-ideological Neo-Luddism}

The spiritual-ideological form of Neo-Luddism attributes non-material, intrinsic value to work, emphasizing the ethical-moral dimension of economic activity. In this trend, dominant religions, ideologies, or para-religious movements 
(e.g. New Age) articulate sceptical attitudes toward mainstream science and technology (i.e. materialist epistemology), and also question the capitalist world of consumption and commodity fetishism. As an example of spiritual-ideological Neo-Luddism (with pastoral elements), one may consider the statement by a sociologist and at the same time a conservative politician: "We must recognize that we cannot cope with endless challenges of an ever-changing kind, either as scientists, as citizens or as human beings. And the scope of changes will not diminish significantly. Yes, we should slow down scientific-technological development - if we want to get to know it better, to understand what it means for the shape of modern civilization, and what it means for humanity. Without this, the suicide of the Enlightenment is inevitable. The deity [of reason] is the part of the Enlightenment heritage which consists in the uncritical sacralisation of all scientific knowledge. There is a strong quasi-religion of scientism, that is, the view that knowledge built upon empirical data is a non-problematic good." [Zybertowicz et al. 2015: 446-452]

This concept is different from the popular idea of "sustainable development" in many ways. In addition to the inconsistent relationship to the status of scientific knowledge, cognition and critical thinking, spiritual Neo-Luddism is a distinctly religious concept, with the idea of clearly defined centres of power over "social forces" (and it does not mean democratic co-management based on rational thought). Perhaps there is a social potential for the emergence of theocracy in the West, but it is dubious what this attitude (ideology) would bring to science, sociology, or politics, or how it would solve problems of industrial civilization. Can the "self-repair of scientific and technical civilization" reconcile various religious strands, which developed a range of different anthropologies of humanity, as well as attitudes toward capitalism and labour? In general, everything that has been proposed here is repetitive, and the critical approach to the vast and diverse intellectual heritage of the Enlightenment seems to be false: why save something that is in any case doomed to destruction, and is evil from the point of view of Catholic human anthropology?

Spiritual-ideological Neo-Luddism calls for the rejection of the Enlightenment dogma of productivity, rationality, profit, and consumerism, which corresponds to the model of the economic man, selfish and individualistic. The cultural discourse landscape of industrialized countries has long contained an opposition to the domination of mass pop culture over local cultures, a contestation of the fetishization of economic growth and its quantitative indicators, (e.g. GDP), and in its place postulates the development of spirituality, a work-life balance, and religious or secular forms of humanization of labour relations. Pragmatists 
of this trend propose to complement or replace the standard tools of measuring growth with development indicators, thus blurring the traditional concept of progress with subjective or qualitative concepts. Spiritual-ideological Neo-Luddism resembles the economic variant in terms of limiting capitalist development. It differs in that it assumes a social ideology, rather than basing its action merely on economic pragmatism (which, incidentally, is also an ideology, hidden in methodological individualism).

From the perspective of institutional change, this conservative attitude is a manifestation of the so-called 'dynamics of stagnation' [Chmielewski 2011: 221], which, in the socio-economic dimension, is manifested in the affirmation of existing conditions.

\section{Anarchic Neo-Luddism}

Although Neo-Luddism is grounded in opposition to the effects of technological advances, all of the aforementioned strands treat the appearance of robots or the Internet neutrally, as a phenomena appearing in the logic of technological development, but rarely seen as a root cause of technological unemployment. Anarchist Neo-Luddism, on the other hand, makes a direct reference to the original sabotage tactics used by the French and British Luddites. It is a separate type of attitude in which the state, technosphere, and science are attacked using the means and methods appropriated from the "enemy." Researchers classify this group as including: anarchoprimitivists, cultural saboteurs, off-grid movements, cyberpunk counterculture, technological libertarians, hackers, and especially, crackers. A sub-category of the off-grid movement are the so-called preppers, i.e. people permanently prepared for a catastrophe: preparing shelters, stockpiling food, wearing emergency gear, learning archaic survival methods, etc. In the United States alone, the number of people preparing for a disaster has been estimated at five million by counting Facebook likes of fanpages. This strand includes the actions of such anarchists as Timothy C. May (BlackNet). By means of cryptography he created a market for information on which undetectable and untaxable transactions could be made, which promoted the development of industrial espionage and trade in military secrets and classified material in the name of government collapse [Brunton, Nissenbaum 2016: 116].

Neo-Luddites are distinguished by their strong emotional dislike of various technological novelties: sometimes even the atavistic destruction of machinery and equipment is permitted, as is the use of violence. The most famous example of such an attitude was the mathematician and assassin Theodore Kaczynski (aka the 
Unabomber), who in the years 1978-1995 sent bombs in letters to random people. Kaczynski intended to fight the "evil" resulting from technological progress, which he conflated with the imagined infantilization of culture. According to Kaczynski [2010], modern technology deprives people of freedom and leads to their "over-socialization", depriving them of the "process of power" - by which he understood individual responsibility for satisfying basic needs such as food or safety. ${ }^{11} \mathrm{He}$ also attributed independent effects to technology per se, beyond its embeddedness in any socio-economic system: "It is not possible to make a lasting compromise between technology and freedom, because technology is by far the more powerful social force. ${ }^{12}$ [Kaczynski 2010:75]

Kaczynski's social views, though not necessarily his methods, are shared by a large number of Americans, who see the government as a threat to their own freedom and beliefs, sometimes directly questioning the position of official science, such as evolutionism, and instead proposing the theory of "intelligent design", or creationism. Conservative thinkers of republican views, when they think of excessive government interference in individuals' affairs, sometimes use stigmatizing terms such as "liberal ${ }^{13}$ fascism" [Goldberg 2007].

Anarchoprimitivism (exemplified, to some extent, by Kaczynski) is a movement calling for abandoning civilized ways of life and for de-industrialisation of the sphere of labour. The rejection of the achievements of science and technology goes hand in hand with the old call (often attributed to Jean J. Rousseau ${ }^{14}$ ) to "return to nature" (the concept of a "noble savage"), and to develop a retrotopic social order based on natural law rather than the current order based on technological achievements, rationalized by materialist culture and driven by the profit-seeking, led by innovative entrepreneurs and progressive politicians. The characteristics of the life of a "noble savage" are a life in harmony with nature, generosity, and selflessness, innocence, inability to lie, faithfulness to tradition, physical endurance, renunciation of material goods, moral courage, and a natural or innate intelligence which yields "wisdom" as opposed to the "knowledge" supposedly shaped by formal education. The anarchoprimitivists believe that

11 “Kaczynski's actions were murderous and, in my view, criminally insane. He is clearly a Luddite, but simply saying this does not dismiss his argument; as difficult as it is for me to acknowledge, I saw some merit in the reasoning. [Joy 2000: 2-3]."

12 A more mainstream view is the opposite: that freedom creates conditions for technological development; see Florida [2002].

13 "Liberal" in the American sense of the word, i.e. left-wing.

14 Rousseau did not claim that such a state actually existed, but rather used these abstract categories to analyse contemporary affairs. 
technology and science are similarly ideologized as traditional religions. They are even more dangerous to humans, because their paradigms are much more convincing than those based on mystical beliefs. The progress of civilization imposes a monopoly of a (materialistic) point of view. Institutional science is not concerned with anomalies, transcendence, New Age, miracles, paranormality etc.

We sum up this section by listing below the main socio-economic orientations and forms of cultural manifestations associated with different types of Neo-Luddism.

TABLE 1. Socio-Economic orientations and forms of cultural manifestation of Neo-Luddism

\begin{tabular}{|l|l|l|}
\hline $\begin{array}{c}\text { Type of Neo- } \\
\text {-Luddism }\end{array}$ & \multicolumn{1}{|c|}{ Socio-Economic orientation } & \multicolumn{1}{c|}{ Cultural manifestation } \\
\hline Economic & $\begin{array}{l}\text { Moderate rejection of capitalism } \\
\text { Return to a social market economy with } \\
\text { strong state intervention } \\
\text { Policies of "sustainable development" } \\
\text { Reindustrialization and reagrarization }\end{array}$ & $\begin{array}{l}\text { Moderate and/or inconsistent rejection } \\
\text { of some forms of modern technology } \\
\text { or communication } \\
\text { Inconsistent attitude toward environ- } \\
\text { mentalism }\end{array}$ \\
\hline $\begin{array}{l}\text { Romantic- } \\
\text { pastoral }\end{array}$ & $\begin{array}{l}\text { Moderate rejection of capitalism } \\
\text { Hostility to any form of mass industrial } \\
\text { production }\end{array}$ & $\begin{array}{l}\text { (Näve) environmentalism, rejection } \\
\text { of scientific development }\end{array}$ \\
\hline $\begin{array}{l}\text { Spiritual-ideo- } \\
\text { logical }\end{array}$ & Communitarianism (possibly religious) & $\begin{array}{l}\text { Rejection of both technosphere and } \\
\text { social progress }\end{array}$ \\
\hline Anarchic & Anarchy & $\begin{array}{l}\text { Radical (sometimes violent) rejection } \\
\text { of the contemporary order using tools } \\
\text { offered by the technosphere }\end{array}$ \\
\hline
\end{tabular}

\section{CONCLUSIONS}

Model typologies of a dynamic process are convenient for highlighting microtrends, but in theoretical works the boundaries between categories are fluid and constrained by definitions, and real people, assuming contradictory attitudes, do not necessarily realize the existence of an abstract schema of their actions. However, how people see the world around them is important to the process. Neo-Luddist attitudes cannot be reduced to retrotopia or some form of modern neo-Marxism, but form a heterogeneous ideological collage. For example, opposition to certain aspects of economic globalization (the effectiveness of the corporate model) unites atheistic anti-globalists with religious activists, and the promotion of so-called "organic food" and the "return to the nature" links hard-line environmentalists with traditional farmers who act according to environmentalist principles unconsciously. 
In a moderated perspective, except for radical proponents of progress in the extreme technocratic version, most people exhibit some Neo-Luddist qualities, while at the same time accepting a rationalistic interpretation of reality (e.g. the benefits of free internet access), and judge explicitly escapist attitudes as strange, atypical, or simply impractical. On a certain level of needs' satisfaction, the rational logic of action can transgress, although all institutional features of social subsystems are apparently preserved.

Human history has generally developed under stable, static, and progressive conditions in which changes to the natural environment, climate, or culture were so slow that the average person could include them in his or her habits or customs, and adapt to them economically and axiologically within a relatively stable instituFtional order and dominant mythology [cf. Napiórkowski 2014]. The popularity of Neo-Luddism can be framed as crossing a certain point, in which the modern is transformed into the provincial, the healthy into the harmful, the safe into the dangerous, etc. A simple example is a bicycle: a cheap means of transportation for the poor is for many urban dwellers an alternative to public transport, becoming at the same time a symbol of modernity and even status. The urban rationality of jogging, as a counterpoint to sedentary office work, for rural residents is a waste of the energy necessary for manual (paid or unpaid) work. In this light, the cultural dichotomy of urban/cosmopolitan vs rural/provincial is easily overcome with new technologies, while the differences in wealth do not automatically translate into different opportunities for mass consumption.

In the most general sense, Neo-Luddism is a (self)-reflective critique of a permanently transforming industrial civilization, with its "dehumanization" of production relations, urbanization, democratic inclusion, and axiological materialism. Neo-Luddism is different from previous forms of rejection of modernity because of the changes in labour relations and the increasing lack of consensus on what constitutes (paid, sensible) work and what poses a threat to employment. Today's techno-pessimists focus on the social consequences of scientific and technological progress, locating their main enemy both in technology per se, but also (more importantly) in ideas and social groups that introduce changes (rationalists, progressives, pragmatists, positivists, liberals), and in its beneficiaries (politicians, capitalists, the establishment, elites). Recognizing the negative relationship between certain socio-economic transformations and the development of science and technology leads some techno-pessimists towards adaptive rationality, but understood in a non-standard way: emotionally-pragmatically rather than logically-rationally. Facts are as useful as fake-news or myths when it comes to rebellion, opposition, rejection, disapproval, and even hatred directed 
against ideas and people who are incomprehensibly and suspiciously different, threatening or unpredictable. In a word, Neo-Luddism serves as relief from the fear of the strange and the unknown.

\section{REFERENCES}

Barber Benjamin R. 2008. Skonsumowani. Jak rynek psuje dzieci, infantylizuje dorostych i potyka obywateli. Warszawa: Wydawnictwo Muza S.A.

Bauman Zygmunt. 1989. Modernity and the Holocaust. Ithaca: Cornell University Press.

Bauman Zygmunt. 2017. Retrotopia. Cambridge: Polity Press.

Brunton Finn, Helen Nissenbaum. 2016. Zmyl trop. Na barykadach prywatności w sieci. Przewodnik. Wydawnictwo: Wydawnictwo Naukowe PWN.

Brynjolfsson Eric, Andrew McAfee. 2011. Race against the machine. Lexington, Mass.: Digital Frontier Press.

Cataluccio Francesco. 2006. Niedojrzałość. Choroba naszych czasów. Kraków: ZNAK.

Celary Wojciech. 2013. Ekonomia twórczości i wolnego czasu. Wykład inaugurujący rok akademicki 2013-2014 na Uniwersytecie Ekonomicznym w Poznaniu. Source: http://ue.poznan. pl/data/upload/articles/20140113/cdbed2390030020139/wyklad-inauguracyjny2013-profw-cellary.pdf. [accessed 12.11.2016].

Chang Ha-Joon. 2016. Źli samarytanie. Mit wolnego handlu i tajna historia kapitalizmu. Warszawa: Wydawnictwo Krytyki Politycznej.

Chmielewski Piotr. 2011. Homo agens. Instytucjonalizm w naukach spolecznych. Warszawa: Wydawnictwo Poltext.

Dennett Daniel C. 2017. From bacteria to Bach and back: The evolution of minds. New York, London: W. W. Norton \& Company.

Durkheim Emile. 1999. O podziale pracy społecznej. Warszawa: PWN.

Ellul Jacques. 1964. The technological society. New York: Knopf.

Florida Richard. 2002. The rise of the creative class. New York: Perseus Book Group.

Fukuyama Francis. 2008. Koniec człowieka. Konsekwencje rewolucji biotechnologicznej. Kraków: Znak.

Goldberg Jonah. 2007. Liberal fascism. New York: Doubleday.

Greer John Michael. 2016. Retrotopia. Founders House Publishing .

Grint Keith, Steve Woolgar. 1997. The machine at work: Technology, work and organization. Cambridge: Polity Press.

Hobsbawm Eric. 2013. The machine breakers. Source: http://libcom.org/history/machine-breakers-eric-hobsbawm [accessed: 1.09.2017].

Horkheimer Max, Adorno Theodor W. 2002. Dialectic of enlightenment. Philosophical fragments. Stanford, CA: Stanford University Press.

Joy Bill. 2000. Why the future doesn't need us. WIRED Magazine, Source: https://www.wired. com/2000/04/joy-2/ [accessed: 1.09.2017]

Kaczynski Theodore. 2010. Technological slavery. Feral House.

Kołodko Grzegorz W. 2013. Dokąd zmierza świat? Ekonomia polityczna przyszłości. Warszawa: Prószyński i S-ka.

Kruczyński Zenon. 2008. Farba znaczy krew. Gdańsk: Wydawnictwo Słowo/Obraz/Terytoria. 
Kuligowski Waldemar. 2012. Różnicowanie nowoczesności. Nowa debata $w$ antropologii spotecznej. Poznań: Wydawnictwo Nauka i Innowacje.

Lasn Kalle. 2000. Culture jam. New York: Quill.

Lukasiewicz Juliusz. 2000. Eksplozja ignorancji. Czy rozumiemy cywilizację przemystową? Warszawa: Oficyna Naukowa.

Marx Karl. 1887. Capital. A critique of political economy. Vol. 1. Moscow: Progress Publishers.

Mises Ludwig von. 1957. Theory and history. An interpretation of social and economic evolution. New Haven: Yale University Press.

Muszyński Karol. 2016. Świat Ubera potrzebuje luddystów. Res Publica Nowa nr 3/2016 „Praca - frustracja - radykalizacja”. Source: http://publica.pl/teksty/muszynski-swiat-ubera-potrzebuje-luddystow-58670.html [accessed: 05.01.2017].

Napiórkowski Marcin. 2014. Władza wyobraźni. Kto wymyśla co zdarzyło się wczoraj? Warszawa: Wydawnictwo Uniwersytetu Warszawskiego.

Nowak Andrzej W. 2013. „Demokratyzowanie czy neoluddyzm - reforma uniwersytetu wobec wyzwań technonauki”. Praktyka Teoretyczna nr 7/2013: 169-193.

Opara Stefan. 2009. Tyrania złudzeń. Studia z filozofii polityki. Warszawa: Wydawnictwo Literackie MUZA.

Pearce David W., R. Kerry Turner. 1989. Economics of natural resources and the environment. Baltimore: Johns Hopkins University Press.

Pobłocki Kacper. 2017. Kapitalizm. Historia krótkiego trwania. Warszawa: Fundacja Bęc Zmiana.

Rifkin Jeremy. 2016. Społeczeństwo zerowych kosztów krańcowych. Internet przedmiotów. Ekonomia wspótdzielenia. Zmierzch kapitalizmu. Warszawa: Wydawnictwo Studio EMKA.

Roszak Theodore. 1986. The cult of information: The folklore of computers and the true art of thinking. New York: Pantheon.

Sale Kirkpatrick. 1995. Rebels against the future: The luddites and their war on the industrial revolution: Lessons for the computer age. Cambridge, Mass: Perseus Books.

Schumacher Ernst F. 1973. Small is beautiful: A study of economics as if people mattered. Harper Perennial.

Tönnies Ferdinand. 1971. On sociology: Pure, applied, and empirical. Chicago: The University of Chicago Press.

Wiśniewski Jakub Bożydar. 2014. Rozwój technologiczny, neoluddyzm i futurologia. Blog. http:// www.jakubw.com/2014/09/rozwoj-technologiczny-neoluddyzm-i.html [Accessed: 1.9.2017]

Zybertowicz Andrzej, Maciej Gurtowski, Katarzyna Tamborska, Mateusz Trawiński, Jan Waszewski. 2015. Samobójstwo Oświecenia? Jak neuronauka i nowe technologie pustosza ludzki świat. Kraków: Wydawnictwo Kasper. 
Maciej D. Kryszczuk

Michat Wenzel

\section{NEO-LUDDYZM W PERSPEKTYWIE PRACY LUDZKIEJ: DZIŚ I JUTRO}

\section{Streszczenie}

Neo-luddyzm wyrasta z przekonania, że współczesne społeczeństwa nie mogą zmienić (kapitalistycznego) podziału pracy i oficjalnych instytucji regulujących tę sferę. W artykule scharakteryzowano intelektualne źródła neo-luddyzmu, zaproponowano typologię i wskazano na jej konsekwencje dla badań współczesnych rynków pracy. Rozróżniamy cztery typy neo-luddyzmu. Ekonomiczni neo-luddyści (1) kierują się odruchami anty-libertariańskimi i opowiadają za reagraryzacją lub reindustrializacją, aby zapobiec bezrobociu i degradacji społeczności. Postawa ta wiąże się w sferze ekonomicznej z neo-luddyzmem romantyczno-pastoralnym (2), związanym z ruchami ekologicznymi kwestionującymi nowoczesną masową produkcję. Przejawia się on w modzie na wegetarianizm i naturalistyczny eskapizm. Odmiana pastoralna może mieć konotacje religijne. Ponadto wyróżniamy (3) neo-luddyzm duchowo-ideologiczny, który tworzą apologeci grup pierwotnych, takich jak rodzina, naród czy wspólnota religijna; nacisk na wydajność działalności gospodarczej proponują zastąpić wartościami poza ekonomicznymi związanymi z życiem zbiorowym lub samorozwojem osobistym. Charakteryzuje się sceptycyzmem wobec głównego nurtu nauki i techniki oraz, ogólnie rzecz biorąc, epistemologii materialistycznej. Osobnym wątkiem jest tak zwany neo-luddyzm anarchistyczny (4), który bezpośrednio czerpie inspirację z taktyki sabotażu stosowanej przez pierwotnych luddystów. Atakuje państwo, technologię i naukę (technosferę) metodami zapożyczonymi od „wroga”. Jego przedstawicielami są np. anarchoprymitywiści, kulturowi sabotażyści, przedstawiciele kultury cyberpunkowej, hakerzy, itp.

Słowa kluczowe: neo-luddyzm, kapitalizm, podział pracy 